\title{
Stem cell tourism in South Africa: A legal update
}

\author{
M Nöthling Slabbert, ${ }^{1}$ BA, BA Hons, MA, DLitt, LLB, LLD; M S Pepper, ${ }^{2}$ MB ChB, PhD, MD; S Mahomed, ${ }^{3}$ LLB, BCom, LLM, PhD candidate \\ ${ }^{1}$ Department of Jurisprudence, School of Law, University of South Africa, South Africa \\ ${ }^{2}$ Department of Immunology, Faculty of Health Sciences, Institute for Cellular and Molecular Medicine and MRC Extramural Unit for Stem Cell Research \\ and Therapy, University of Pretoria, South Africa; Department of Genetic Medicine and Development, Faculty of Medicine, University of Geneva, \\ Switzerland \\ ${ }^{3}$ Steve Biko Centre for Bioethics, Faculty of Health Sciences, University of the Witwatersrand, Johannesburg, South Africa
}

Corresponding author: M Nöthling Slabbert (slabbmn@unisa.ac.za)

\begin{abstract}
The past few years have seen a sharp rise in the propagation of unproven stem cell 'treatments', also known as 'stem cell tourism'. Patients suffering from a variety of diseases unresponsive to conventional medical therapy often travel to certain destinations to receive these therapies, mostly from bogus operators advertising various 'stem cell treatment cures' for a wide range of conditions, and in the process mislead vulnerable patients with unfounded promises of recovery. Stem cell tourism, made possible by legal lacunae or weak national regulatory frameworks, raises grave legal and ethical concerns, as patients not only receive treatments which are unproven, but often also unregulated, potentially dangerous and fraudulent. Existing proven therapeutic applications using stem cells are limited to those for blood and immunological disorders and are based on clinical trials that have demonstrated the efficacy and safety of these applications. As a result of weak legislative enforcement in this area, South Africa has unfortunately become an attractive destination for fraudulent stem cell operators.

The purpose of this article is provide an update on the South African legal position relating to stem cell therapy by evaluating the effectiveness of the Medicines and Related Substances Act and other relevant legislative provisions in regulating cell-based therapies, drawing strongly on recent international developments and case law in this field. The article will make specific recommendations aimed at improving the existing position.
\end{abstract}

S Afr J BL 2015;8(2 Suppl 1):41-45. DOI:10.7196/SAJBL.8006

Recent years have seen a sharp increase in the number of patients, with a variety of diseases unresponsive to conventional medicines, travelling to various jurisdictions across the world to receive unproven stem-cell based treatments - a phenomenon pejoratively described as 'stem cell tourism! [1] This raises significant ethical concerns, as patients receive treatments that are unproven, often unregulated, potentially harmful, and often fraudulent. ${ }^{[2]}$ Although stem cell therapy (defined as'the use of stem cells for therapeutic purposes ${ }^{\left[{ }^{[3]}\right.}$ is largely still experimental, proven existing therapeutic applications for stem cells (based on clinical trials that have demonstrated the efficacy and safety of these applications) are those used for the treatment of blood or immunological disorders, with bone marrow (BM) derived haematopoietic stem cells (HSCs) having been routinely used for more than 50 years. ${ }^{[4]}$

Despite the existence of regulations governing research with human subjects, as well as medical malpractice and licensing laws in some jurisdictions, guidelines in general are not specific to stem cell therapy. ${ }^{[5]}$ With increased attention following a number of adverse events resulting from some of these unfounded claims, the scientific community has begun to develop guidelines for researchers and physicians involved in the clinical translation of stem cell research. However, despite these efforts and international agreements aimed at addressing this gap ${ }^{[6]}$ not all accept or abide by these rules. The social media is used to advertise these 'miracle' cures as routine therapies and to entice ignorant and desperate patients. The proliferation of these unproven 'therapies', no doubt facilitated by weak regulatory frameworks, also raises serious concerns about the exploitation of desperate and vulnerable patients, the regulation of cell-based therapies generally, as well as the governance of healthcare professionals. ${ }^{[7]}$ It also jeopardises legitimate and inno- vative translational stem cell research, emphasising the need for a clear distinction between reckless and unproven 'therapies' and legitimate, innovative stem cell-based interventions.

Late in 2012, a South African (SA) neurosurgeon, Dr Andre Liebenberg, claimed to have succeeded in paving the way for repairing spinal cord injuries using therapeutic stem cell cloning, by removing $35 \mathrm{~mm}$ from the spinal cord of a quadriplegic man and injecting a 'special' matrix containing these cells into the defect. ${ }^{[8]}$ It subsequently emerged that, at that time, neither the neurosurgeon, nor his partner, Dr Gert Jordaan, had obtained prior ethical approval, subjected their work to peer review, published any of their research, or secured approval from the Medicines Control Council. ${ }^{[8]}$ Their research has since been published. ${ }^{[9]}$ Questioned at the time by the country's stem cell experts, this example, conducted as an experimental treatment with the informed consent of the patient, was made possible by the legal lacunae that created opportunities for the development of unethical and unregulated practices in the stem cell field. ${ }^{[8]}$ This example is relevant as it also illustrates the fine balance between scientific soundness in medical advancement, and uncontrolled experimental treatments that abuse patient vulnerability and compromise patient safety.

The SA population is particularly vulnerable in this regard, as limited information is available to provide South Africans with relevant, reliable and accurate information with regard to current, future or potential stem cell treatments. ${ }^{[4]}$ In addition, physicians and healthcare providers are not informed of recent developments on a global front in this regard, nor of the legal implication in the South African context. ${ }^{[4]}$

The purpose of this article is to provide an update on the SA legal position relating to stem cell therapy, by discussing relevant requirements contained in the Medicines and Related Substances Act and regulations, 
as well as other relevant legislative provisions in regulating cell-based therapies, drawing strongly on recent international developments and case law in this field. The article concludes with recommendations aimed at improving the existing position.

\section{Some ethical, legal and scientific issues relating to unproven stem cell treatments Safety, efficacy and quality}

Unproven therapies generally fail to comply with relevant minimal ethical, scientific or medical standards of safety and efficacy which clinical trials set out to determine. An assessment of the balance between risks and benefits associated with the intervention is not undertaken, not to mention the absence of measures aimed at ensuring that patients (or participants) understand the key issues of the therapy, which includes a realistic description of prospective benefits, particularly in instances where an intervention has never been done before and patients' hopes are high.

Unproven 'treatments' or 'therapies', mostly experimental in nature, are marketed as being successful based on unreliable and anecdotal evidence, including self-reports from patients. ${ }^{[2]}$ Post-treatment care is seldom provided and there is no follow-up monitoring of patients or reporting of adverse events. ${ }^{[1]}$ In addition, patients are charged excessive amounts for the therapy, which is a departure from the accepted norm that a provider of an experimental treatment does not charge a patient for the treatment.

Stem cell-based interventions are associated with medical risks, which may include tumour growth, immunological reactions, unexpected or unpredictable cell behaviour, as well as unknown long-term health consequences. ${ }^{[10]}$ Producing and testing stem cells for quality in sufficient batches is another challenge. As transplanted stem cells remain in the bodies of patients for many years, side-effects and long-term safety should be determined.

Evidence of safety should be determined through appropriate preclinical studies in relevant animal models or through human studies involving similar cell-based interventions, with stricter requirements for safety where cells were manipulated ex vivo or were derived from induced pluripotent stem cells (iPSCs). ${ }^{[10]}$ Medical trials involving experimental drugs may pose other complications, such as compensation claims for non-medical-related injuries, as was the focus of a recent landmark decision (the Roche ${ }^{[11]}$ decision) in South Africa. Key principles of importance for this article emerging from the Roche judgment are that:

- Regulators are responsible for assessing and approving the nature of the compensation for research-related injuries when reviewing and approving a study.

- Research participants are bound by the terms contained within the informed consent document approved by these regulators and any amendment thereto should be in writing and duly communicated to and noted by the regulator in order to be legally binding.

- An adequate informed consent process that distinguishes between researchers and sponsors and the limitation of compensation must be implemented.

- Delictual claims for research-related injuries will not succeed if a plaintiff has signed an informed consent document limiting his or her rights and which limits compensation. ${ }^{[11]}$

\section{Ethical oversight and patient protection}

Unproven stem cell 'treatments' are often not part of clinical trials; no independent ethics review by recognised institutional review boards or ethics committees takes place and the research is not published in peer-reviewed journals, which makes replication of the research impossible. ${ }^{[1]}$ Treatments are often offered in countries where it is difficult to institute medical negligence actions. ${ }^{[1]}$

The National Health Act (NHA) stipulates that all health research which involves human participants requires an independent review by an accredited and registered research ethics committee. Institutions conducting health research (e.g. private institutions and universities) must have an ethics committee or have access to one which is registered and accredited by the National Health Research Ethics Council. ${ }^{[12]}$ The composition and operating procedures of ethics committees are described in the Act. ${ }^{[13]}$ It is of utmost importance that because of possible unforeseen consequences and long-term health risks to participants or patients, ongoing regulatory oversight, once ethics approval has been granted, takes place.

Procedures to obtain voluntary informed consent from patients signing up for unproven therapies are often inadequate. Informed consent should strive to eliminate any possible misconceptions regarding therapeutic efficacy of the treatment, which is unlikely in the case of unproven treatments. The source of the stem cells should also be disclosed, for example cells derived from human fetuses or human embryonic stem cells (hESCs), which some patients may object to on moral grounds. In the case of some unproven treatments, a variety of cell sources are used, some even including animal tissue. ${ }^{[4]}$

Where stem cell procedures are part of stem cell clinical trials, it is imperative that research ethics committees or institutional review boards consist of members with specific expertise in stem cell research and its clinical translation. Chapter 9 of the NHA sets out the requirements regarding research on or experimentation with human subjects, as well as those relating to health research ethics committees.

\section{Patient autonomy}

It is trite that the ultimate decision to undergo or refuse a medical intervention is that of the patient and not the doctor. ${ }^{[14]}$ This is also the case, if from the point of view of the medical profession, a patient's refusal seems grossly unreasonable and might result in his or her death, and even if the medical practitioners involved take the view that disclosure of the risks and dangers in such circumstances is unnecessary or undesirable. ${ }^{[15]} \mathrm{As}$ far as the context of stem cell therapy is concerned, it should be noted that patient autonomy, derived from the right to self-determination embodied in section 12 of the Constitution ${ }^{[16]}$ which refers to the right to bodily and psychological integrity, has been statutorily reinforced in the following sections of the NHA: ${ }^{[17]}$ section 6 'User to have full knowledge'; section 7 'Consent of user'; section 8 'Participate in decisions'; section 11 'Health services for experimental and research purposes' and section 71 'Research on or experimentation with human subjects'. In addition, section 16(1)(d) of the same Act provides that healthcare providers must inform patients of their right to refuse healthcare services, and that they need to explain the implications, risks and obligations attached to such refusal.

Patient autonomy, however, is not absolute and will be limited, depending on the circumstances. For example, patient consent to illegal or grossly negligent procedures (e.g. wanton experimentation) will be regarded as contra bonos mores, in other words, against the legal convictions of society or public policy. The consent of a fugitive to plastic surgery to mask his identity in order to escape prosecution is an example of invalid consent. ${ }^{[15]}$ Patient autonomy is furthermore tempered by the implementation of the principles of beneficence, non-maleficence, justice 
and fairness, which, in the case of unproven therapies, may point to an obligation on the part of those providing the treatment to act in the best interests of the patient and not to cause harm. Registered healthcare providers who provide dangerous and unproven stem cell therapies may face disciplinary action from their respective professional bodies. ${ }^{[18]}$

\section{Distributive justice}

The broad potential public benefit offered by stem cell research requires a consideration of difficult questions relating to social and distributive justice, in particular as far as access to these treatments is concerned. Patients in developing countries have limited access to cell therapy as a therapeutic option. Developing countries, such as $\mathrm{SA}$, are facing many challenges in ensuring that basic medical services are established and maintained. The need for specialised forms of treatment, such as cell-based therapies, is therefore questioned. ${ }^{[19]}$

\section{Regulation of stem cell treatments International Society for Stem Cell Research (ISSCR)}

The International Society for Stem Cell Research is an independent, non-profit organisation that represents more than 4000 members of the stem cell research community. The ISSCR's Guidelines for the Clinical Translation of Stem Cells, ${ }^{[20]}$ compiled by a group of stem cell researchers, ethicists, clinicians and regulatory officials from thirteen countries, condemns unproven use of stem cells or their direct derivatives to patients outside of a clinical trial, particularly when patients have to pay for such services. ${ }^{[21]}$ As a matter of professional ethics, scientists, healthcare and research institutions should not participate in such activities. In countries where unproven therapies are offered, the regulators should work to prevent the exploitation of patients and, where relevant, take disciplinary steps against those clinicians involved and close down the fraudulent clinics. The ISSCR guides individuals in making informed choices when contemplating a stem cell-based intervention either locally or abroad. ${ }^{[22]}$

\section{Professional ethical guidelines and medico- ethical codes of conduct}

The conduct of doctors and the practice of medicine are governed by existing international and several national medico-ethical codes of conduct. Among national medico-ethical codes, the most important are the rules of conduct of the Health Professions Council of South Africa (HPCSA) and the guidelines on ethics for medical research of the South African Medical Research Council (MRC).

Some of the guidelines relevant to the provision of treatment which overlap with guidelines regarding research are the following:

- Guidelines for Good Practice in the Health Professions (HPCSA, booklet 2):[23] 'A practitioner shall in the conduct and scope of his or her practice, use only - (a) a form of treatment, apparatus or health technology which is not secret and which is not claimed to be secret; and (b) an apparatus or health technology which proves upon investigation to be capable of fulfilling the claims made in regard to it' (par 19).

- Guidelines on Overservicing, Perverse Incentives and related matters (HPCSA, booklet 5): ${ }^{[23]}{ }^{\prime} H$ Health care practitioners shall not [...] provide a service or perform procedures [...] on a patient that are neither indicated nor scientific or have been shown to be ineffective, harmful or inappropriate through evidence-based review' (par 3.1.1).

- General Ethical Guidelines for Biotechnology Research (HPCSA, booklet 7), ${ }^{[23]}$ which contains instructive guidelines on a range of activities in the context of biotechnology research, including stem cell research (but not its clinical translation).

- General Ethical Guidelines for Health Researchers (HPCSA, booklet 6):[23]' Health researchers should [...] fully inform research participants about which aspects of medical care, if any, are related to health research, and clearly distinguish between therapeutic interventions and health research processes' (par 6.6.4).

- Guidelines on Ethics for Medical Research (MRC, 2004), ${ }^{[24]}$ which contain guidelines regarding research involving innovative therapy or intervention (par 5.10), as well as detailed guidelines regarding the conduct of clinical trials and the use of human tissue samples.

- Guidelines for Good Practice in the Conduct of Clinical Trials on Human Participants in South Africa (Department of Health, 2006), ${ }^{[25]}$ which address general ethical issues with regard to clinical trials involving human participants.

Scientific experimentation and clinical trials, be they therapeutic or non-therapeutic, or beneficial to the patient or beneficial to others, are legally permissible provided they conform to the fundamental principles of informed consent to treatment, emergency treatment, the duty of reasonable care and with considerations of public policy in the particular circumstances. ${ }^{[2]}$ Should an action for damages or a criminal charge flowing from harm allegedly suffered in consequence of improper or unacceptable experimentation arise, courts will be guided by the relevant ethical guidelines, such as those referred to above, as well as generally acknowledged international codes and declarations on human experimentation and a wide range of international declarations on human rights in general. ${ }^{[26]}$

\section{Statutory framework}

The registration of medicines in South Africa is governed by the provisions and requirements of the Medicines and Related Substances Control Act ${ }^{[27]}$ (MRSCA). The aim of the Medicines Control Council (MCC), a statutory body established in terms of the MRSCA, is to protect and safeguard the public by ensuring that all medicines sold and used in SA are safe, therapeutically effective and that these medicines meet relevant and acceptable standards of quality. ${ }^{[28]}$

The MCC's Guidelines for the Registration of Medicines: General Information ${ }^{[29]}$ aim to assist applicants in the preparation of documentation for the registration of medicines for human use. ${ }^{[30]}$ Legislation requires that the MCC shall register every medicine before it may be sold or marketed. ${ }^{[31]}$ An application for the registration of a medicine should therefore be submitted for evaluation and approval.

The nature of a stem cell therapy is unique and different from conventional medicines. It may include characteristics and components of a 'health service,', which include medical treatment, ${ }^{[32]}$ 'therapeutic' or 'non-therapeutic research, ${ }_{1}^{\text {[33] }}$ or 'health services for experimental or research purposes, as described in the NHA. ${ }^{[34]}$ Each of these has different legal and ethical considerations, ${ }^{[34]}$ depending on whether one views cell-based therapy as a form of medical treatment, experimental research or medicine. ${ }^{[35]}$ Stem cells used in HSC transplantation, essentially a stem cell intervention in existence for some decades as part of the treatment for certain haematological cancers and other disorders, are not registered with the MCC as a medicine, but an HSC transplantation requires, in addition to the written informed consent of the persons from whom the cells are removed, ministerial authorisation. ${ }^{[36]}$ 
The MCC prohibits the sale of medicine which is subject to registration but not registered. ${ }^{[37]}$ An exception would be where such medicine is compounded in the course of the person carrying on of his or her profession by inter alia a medical practitioner for a particular patient, 'in a quantity not greater than that required for treatment as determined by the medical practitioner ${ }^{\prime[38]} \mathrm{A}$ particular substance must be used relatively widely for therapeutic purposes and not only on a 'single occasion' in order for the substance to qualify as a 'medicine' in terms of the Medicines Act. ${ }^{[39]}$

The Medicines and Related Substances Control Act (MRSCA) defines a medicine as:

'any substance or mixture of substances used or purporting to be suitable for use or manufactured or sold for use in -

(a) the diagnosis, treatment, mitigation, modification or prevention of disease, abnormal physical or mental state or the symptoms thereof in man; or

(b) restoring, correcting or modifying any somatic or psychic or organic function in man, and includes any veterinary medicine. ${ }^{\{40]}$

Biological medicines, a highly specialised class or type of medicine, produced using living organisms, are complex protein structures typically much larger than traditional chemical medicines and are mostly administered by injection. ${ }^{[1]}$ An example would be insulin used for the treatment of diabetes. Biological medicines are more advanced than conventional therapies and provide prescribers with enhanced tools for treating patients. ${ }^{[4]}$ Though clinically effective, these medicines are very expensive in SA. ${ }^{[4]}$

The MRSCA does not define a biological medicine, but the guideline referred to above, ${ }^{[42]}$ defines a biological medicine (categorised as a type of medicine) as follows:

'A medicine where the active ingredient and/or key excipients have been derived from living organisms or tissues, or manufactured using a biological process. Biological medicines can be defined largely by reference to their method of manufacture (the biological process). These include inter alia medicines prepared from the following substrates:

(i) Microbial cultures (fermentation);

(ii) Plant or animal cell cultures (including those resulting from recombinant DNA or hybridoma techniques);

(iii) Extraction from biological tissues; and

(iv) Propagation of live agents in embryos or animals.

The living substrate may be genetically modified in a number of ways to provide the required active ingredient, including recombinant DNA technology or hybridoma techniques.

Biological Medicines include, but may not be limited to the following:

(i) Plasma-derived products, e.g. clotting factors, immunosera, etc;

(ii) Vaccines;

(iii) Biotechnology-derived medicinal products (rDNA products) e.g. rHuantihemophilic factors, hormones, cytokines, enzymes, monoclonal antibodies, erythropoietins;

(iv) Human gene therapy.'

Based on ii and iii in the first section above, a stem cell product (or stem cell application) would therefore fall within the ambit of a biological medicine. ${ }^{[43]}$ It will, however, be important to be more explicit about stem cells and their applications in any revision of these guidelines in the future.

Moreover, as far as the harvesting of the stem cells for therapeutic use is concerned, the harvesting, isolation, cryopreservation and any other activity in relation to these cells must comply with the relevant requirements stipulated in chapter 8 of the $\mathrm{NHA}^{[44]}$ and relevant regulations, such as the regulations relating to the use of human biological material. An example of a present regulatory inconsistency that creates many practical obstacles in respect of routine procedures, (e.g. bone marrow transplantation), is that the requirement of ministerial authorisation for the removal of stem cells from living persons (the latter being the step preceding the use of the cells for therapeutic purposes) is mentioned in the Act itself, but not in the regulations (relating to the use of human biological material). ${ }^{[45]}$ The Regulations relating to Stem Cell Banks ${ }^{[4]}$ furthermore state that no person may release stem cells products for therapeutic use unless this activity is authorised in terms of section 54 of the NHA and laboratory tests for certain transmissible diseases have been performed, where relevant. ${ }^{[4]]}$ In addition, no person may use stem cell products for therapeutic purposes unless he or she is registered with the department ${ }^{[48]}$ and, among others, relevant written (and duly documented voluntary) consent has been obtained from the donor of the cells, even in the case of residual tissue, blood or blood products. ${ }^{[49]}$

Since the MRSCA requires that the MCC shall register every medicine before it may be sold and marketed, an application for the registration of a medicine should be submitted for evaluation and approval. ${ }^{[50]}$ Applications for registration of a medicine for use in humans are divided into different types for the determination of fees and allocation to reviewers for evaluation. ${ }^{[51]}$ As such, a biological medicine is one of the types of medicines applications. It is a legal requirement that data submitted for evaluation, by the applicant, should substantiate all claims and should meet the technical requirements of quality, safety and efficacy. The MCC refers to international guidelines to be read in conjunction with the SA guidelines. In particular, the MCC refers to the International Conference on Harmonization $(\mathrm{ICH})$ of Technical Requirements for Registration of Pharmaceuticals for Human Use, the mission of which is to achieve greater harmonisation to ensure that safe, effective and high-quality medicines are developed and registered in the most resource-efficient manner. ${ }^{[52]}$

The ICH promotes public health, prevents unnecessary duplication of clinical trials in humans, and minimises the use of animal testing without compromising safety and effectiveness. ${ }^{[53]}$ Therefore, any applicant for the registration of a medicine must ensure that the technical requirements of quality, safety and efficacy of the product for the purposes for which it is intended, have been met. After submission of the relevant administrative steps for the registration of a medicine (including a biological medicine), ${ }^{[54]}$ these biological medicines (containing or derived from living materials) require primary evaluation by the Biological Medicines Committee, in addition to other committees of the MCC. The MCC may choose to accept, defer, or reject the application. Should the application be deferred, the applicant will be required to produce additional information and re-submit the application for approval. Once the application is accepted, the biological medicine is registered with the MCC and may be sold and marketed. ${ }^{[1]}$

Failure to register a stem cell therapy in the manner prescribed constitutes a contravention of section 14(1) of the MRSCA and hence an offence in terms of section 29 , punishable by a fine or imprisonment of a period not exceeding 10 years. ${ }^{[55]}$

\section{Conclusion}

The brief discussion of the relevant regulatory framework, as well as some of the attendant legal, ethical and scientific concerns and complexities, points to a need for an unambiguous and coherent legal framework for the regulation of cell therapy. This is borne out by the rise in unproven therapies globally. The unique nature of cell therapy makes the conventional 
medicines regulatory model a difficult fit for the proper legal regulation of this fast evolving and dynamic therapeutic field. Close scrutiny of chapter 8 of the NHA, including regulations promulgated in terms of the Act relevant to stem cell research and therapy, is required, to close any regulatory gaps that may facilitate the promotion of unproven cell therapies. Inconsistent or conflicting statutory provisions, regulations and guidelines governing both research and clinical application may inadvertently expose vulnerable patients to possible exploitation by bogus stem cell therapy operators. As stated in the introduction, some physicians are already practising unregulated cell therapy in SA, with grave potential consequences. Access to novel therapies also raises pertinent issues regarding distributive justice and access to these treatments in a developing country where access to basic healthcare services is already severely compromised. Public educational programmes that provide the public with accurate and reliable information regarding legitimate and authentic existing cell therapies are critical, and should ideally include the provision of a platform (website or hot line) to which suspect stem cell activities could be reported.

Funding: This research and the publication thereof is the result of funding provided by the Medical Research Council of South Africa in terms of the MRC's Flagships Awards Project SAMRC-RFA-UFSP-01-2013/ STEM CELLS.

\section{References}

1. Mahomed S, Slabbert MN. Stem cell tourism in South Africa: The legal position. S Afr J BL 2012;5(2):69-73. [http://dx.doi.org/10.7196/SAJBL.235]

2. Mahomed S. A legal framework for the regulation of stem cell research and therapy in South Africa. 2012. LLM dissertation, University of South Africa.

3. Republic of South Africa. Regulations on the Use of Human Biological Material. Government Notice R177, Government Gazette 35099 of 2 March 2012. Pretoria: Government Printer, 2012: regulation 1.

4. Meissner-Roloff M, Pepper, M. Curbing stem cell tourism in South Africa. Applied \& Translational Genomics (2013):22-27. [http://dx.doi.org/10.1016/j.atg.2013.05.001]

5. Master Z, Resnik DB. Stem cell tourism and scientific responsibility. EMBO Rep 2011;12(10):992-995. [http://dx.doi.org/10.1038/embor.2011.156].

6. International Society for Stem Cell Research. Guidelines for the Clinica Translation of Stem Cells. ISSCR 3 December, 2008). http://www.isscr.org/docs/ guidelines/isscrglclinicaltrans.pdf (accessed 1 February 2015).

7. Lysaght T, Kerridge I, Sipp D, et al. Oversight for clinical uses of autologous adult stem cells: Lessons from international regulations. Cell Stem Cell 13, 2013;13(6)::647-651. [http://dx.doi.org/10.1016/j.stem.2013.11.013].

8. Bateman, C. 'Pioneer' Paarl neuro sets alarm bells ringing. S Afr Med J 2013; 103(1):8-9. [http://dx.doi.org/10.7196/SAMJ.6587]

9. Du Toit DF, Liebenberg WA. Somatic-cell nuclear transfer: Autologous embryonic intra-spinal stem cell transplant in a chronic complete quadriplegic patient. Neuro-anatomical outcome after one year. Revista Argentina de Anatomía Clinica 2014;6(1):35-42

10. Hyun I, Lindvall O, Ahrlund-Richter L, et al. New ISSCR guidelines underscore major principles for responsible translational stem cell research. Cell Stem Cell 2008;3(6):607-609. [http://dx.doi.org/10.1016/j.stem.2008.11.009]

11. Venter v. Roche Products (Pty) Limited and Others. Western Cape High Court of South Africa, 12285/08. Judgement delivered on 7 May 2013.

12. Republic of South Africa. National Health Act 61 of 2003. Pretoria: Government Printer, 2003: section 73.

13. Republic of South Africa. National Health Act 61 of 2003. Pretoria: Government Printer, 2003: section 72

14. Castell v. De Greef 1994 (4) SA 408 (C) at 420-421.

15. Slabbert MN. Medical Law: South Africa. In: Nys H, ed. International Encyclopaedia of Laws. Alphen aan den Rijn, NL: Kluwer Law International, 2014: par 125.

16. Republic of South Africa. Constitution of the Republic of South Africa, 1996. Pretoria: Government Printer, 1996.

17. Republic of South Africa. National Health Act 61 of 2003. Pretoria: Government Printer, 2003: , sections 6-8, 11, 16(1)(d) and 71.

18. Republic of South Africa. Health Professions Act 56 of 1974. Pretoria: Government Printer, 1974: , section 3.

19. Jackson CS, Pepper MS. Opportunities and barriers to establishing a stem cell programme in South Africa. Stem Cell Research \& Therapy 2013;4(3):54:1-7 [http://dx.doi.org/10.1186/scrt204].

20. International Society for Stem Cell Research. Guidelines for the Clinical Translation of Stem Cells. ISSCR, 3 December, 2008). http://www.isscr.org/docs/ guidelines/isscrglclinicaltrans.pdf (accessed 1 February 2015).

21. International Society for Stem Cell Research. Guidelines for the Clinical Translation of Stem Cells. ISSCR 3 December, 2008 at 5. http://www.isscr.org/ docs/guidelines/isscrglclinicaltrans.pdf (accessed 1 February 2015).

22. International Society for Stem Cell Research. Guidelines for the Clinical Translation of Stem Cells. ISSCR, 3 December, 2008 at 4. http://www.isscr.org/ docs/guidelines/isscrglclinicaltrans.pdf (accessed 1 February 2015).

23. Republic of South Africa. Health Professions Council of South Africa. Pretoria: HPCSA, 2008.

24. Republic of South Africa. Medical Research Council. Cape Town: MRC, 2004.

25. Republic of South Africa. Pretoria: National Department of Health, 2006

26. Slabbert MN. Medical Law: South Africa. In: Nys H, ed. International Encyclopaedia of Laws. Alphen aan den Rijn, NL: Kluwer Law International, 2014: par 292.

27. Republic of South Africa. Medicines and Related Substances Control Act 101 of 1965. Pretoria: Government Printer, 1965.

28. Republic of South Africa. Medicines Control Council. http://www.mccza.com (accessed 21 February 2015).

29. Republic of South Africa. Medicines Control Council. Guidelines for the Registration of Medicines: General Information. Pretoria: Government Printer, 2012.

30. Republic of South Africa. Medicines Control Council. Guidelines for the Registration of Medicines. Pretoria: Government Printer, 2012:par 1.

31. Republic of South Africa. Medicines and Related Substances Act 101 of 1965. Pretoria: Government Printer: section 14.

32. Republic of South Africa. National Health Act 61 of 2003. Pretoria: Government Printer, 2003: section 1.

33. Republic of South Africa. National Health Act 61 of 2003. Pretoria: Government Printer, 2003: sections 71(2) and 71(3).

34. Republic of South Africa. National Health Act 61 of 2003. Pretoria: Government Printer, 2003: section 11.

35. Van Wyk C. Legal issues surrounding stem cell research, including consent. Unpublished paper delivered at the conference on Legal Aspects relating to the Applications of Biotechnology, University of South Africa. 21 August 2012:9-11.

36. Republic of South Africa. National Health Act 61 of 2003. Pretoria: Government Printer, 2003: section 56.

37. Republic of South Africa. Medicines and Related Substances Act 101 of 1965. Pretoria: Government Printer, 1965: section 14(1).

38. Republic of South Africa. Medicines and Related Substances Act 101 of 1965. Pretoria: Government Printer, 1965: section 14(4).

39. Reitzer Pharmaceuticals (Pty) Ltd v. Registrar of Medicines and Another 1998 (4) SA 660 (T) at 682-3.

40. Republic of South Africa. Medicines and Related Substances Act, section 1(1) Government Gazette 1965.

41. Carapinha, JL. Policy guidelines for risk-sharing agreements in South Africa. SA Fam Pract 2008; 50(5):43-46.

42. Medicines Control Council. Guidelines for the Registration of Medicines: General Information. Pretoria: Government Printer, August 2012: par 2.7.5.

43. Jordaan D. Regulatory crack-down on stem cell therapy: What would the position be in South Africa? S Afr Med J 2012;102(4):219-220.

44. Republic of South Africa. National Health Act 61 of 2003. Pretoria: Government Printer, 2003: sections 6; 11, 55, 56(2)(a)(iv), 56(2)(b), and 56(2)9(b)).

45. Republic of South Africa. Government Notice R177 in Government Gazette 35099 of 2 March 2012. Pretoria: Government Printer, 2012.

46. Republic of South Africa. Goverment Notice R183 in Government Gazette 35099 of 2 March 2012. Pretoria: Government Printer, 2012: regulation 2.

47. Republic of South Africa. Regulations relating to Stem Cell Banks. Government Notice R183 in Government Gazette 35099 of 2 March 2012. Pretoria: Government Printer, 2012: regulation 2(1).

48. Republic of South Africa. Regulations relating to Stem Cell Banks. Government Notice R183 in Government Gazette 35099 of 2 March 2012. Pretoria: Government Printer, 2012: regulation 3(3)(a).

49. Republic of South Africa. Regulations relating to Stem Cell Banks. Government Notice R183 in Government Gazette 35099 of 2 March 2012. Pretoria: Government Printer, 2012: regulation 2(3).

50. Republic of South Africa. Medicines Control Council. Guidelines for the Registration of Medicines. Pretoria: Government Printer, 2012: par 2.7.

51. Republic of Souh Africa. Medicines Control Council. Guidelines for the Registration of Medicines. Pretoria: Government Printer, 2012: par 2.7.

52. Kuhnert, BR. Global Forum; 2011:3(2):17. http://www.google.co.za/url?url=http:// www.ich.org/fileadmin/Public_Web_Site/News_room/C_Publications/DIA_Global_ Forum_Harmonization_articles_I_2011 pdf\&rct=j\&frm $=1 \& q=\&$ esrc $=s \& s a=U$ Uved $=0$ CBMQFjAAahUKEwjporix6ujGAhUDcNsKHUjPDdg\&sig2=fDFfJVW3jqAJZkREkMu9 A\&usg=AFQjCNEnnzYNTJ3buztlbpDT69q4msra9A (accessed 20 July 2015).

53. ICH: Harmonisation for better health. FAQ. Switzerland. http://www.ich.org/ about/faqs.html (accessed 28 July 2012).

54. Republic of South Africa. Medicines Control Council. Guidelines for the Registration of Medicines. Pretoria: Government Printer, 2012: paras 3 and 4.

55. Republic of South Africa. Medicines and Related Substances Act 101 of 1965 Pretoria: Government Printer, 1965 